\title{
openheart Home-based versus centre-based cardiac rehabilitation: abridged Cochrane systematic review and meta-analysis
}

\author{
S A Buckingham, ${ }^{1}$ R S Taylor, ${ }^{2} \mathrm{~K}$ Jolly, ${ }^{3}$ A Zawada, ${ }^{4}$ S G Dean, ${ }^{2}$ A Cowie, ${ }^{5}$ \\ R J Norton, ${ }^{6} \mathrm{H}$ M Dalal ${ }^{1,2}$
}

To cite: Buckingham SA, Taylor RS, Jolly K, et al. Home-based versus centrebased cardiac rehabilitation: abridged Cochrane systematic review and meta-analysis. Open Heart 2016;3:e000463 doi:10.1136/openhrt-2016000463

- Additional material is available. To view please visit the journal (http://dx.doi.org/ 10.1136/openhrt-2016000463).

Paper based on: Taylor RS, Dalal H, Jolly K, et al. Homebased versus centre-based cardiac rehabilitation. Cochrane Database Syst Rev 2015;(8):CD007130.

Received 28 April 2016 Revised 24 June 2016 Accepted 19 July 2016

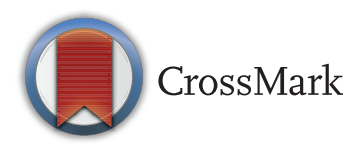

For numbered affiliations see end of article.

Correspondence to Professor RS Taylor; r.taylor@exeter.ac.uk

\section{ABSTRACT}

Objective: To update the Cochrane review comparing the effects of home-based and supervised centre-based cardiac rehabilitation (CR) on mortality and morbidity, quality of life, and modifiable cardiac risk factors in patients with heart disease.

Methods: Systematic review and meta-analysis. The Cochrane Central Register of Controlled Trials (CENTRAL), MEDLINE, EMBASE, PsycINF0 and CINAHL were searched up to October 2014, without language restriction. Randomised trials comparing home-based and centre-based CR programmes in adults with myocardial infarction, angina, heart failure or who had undergone coronary revascularisation were included.

Results: 17 studies with 2172 patients were included. No difference was seen between home-based and centre-based CR in terms of: mortality (relative risk (RR) $0.79,95 \% \mathrm{Cl} 0.43$ to 1.47 ); cardiac events; exercise capacity (mean difference (MD) $-0.10,-0.29$ to 0.08 ); total cholesterol (MD $0.07 \mathrm{mmol} / \mathrm{L},-0.24$ to 0.11 ); low-density lipoprotein cholesterol (MD $-0.06 \mathrm{mmol} / \mathrm{L},-0.27$ to 0.15 ); triglycerides (MD $-0.16 \mathrm{mmol} / \mathrm{L},-0.38$ to 0.07 ); systolic blood pressure (MD $0.2 \mathrm{~mm} \mathrm{Hg},-3.4$ to 3.8); smoking (RR 0.98, 0.79 to 1.21 ); health-related quality of life and healthcare costs. Lower high-density lipoprotein cholesterol (MD $-0.07 \mathrm{mmol} / \mathrm{L},-0.11$ to -0.03 , $\mathrm{p}=0.001)$ and lower diastolic blood pressure (MD $-1.9 \mathrm{~mm} \mathrm{Hg},-0.8$ to $-3.0, p=0.009$ ) were observed in centre-based participants. Home-based CR was associated with slightly higher adherence (RR 1.04, 95\% $\mathrm{Cl} 1.01$ to 1.07 ).

Conclusions: Home-based and centre-based CR provide similar benefits in terms of clinical and healthrelated quality of life outcomes at equivalent cost for those with heart failure and following myocardial infarction and revascularisation.

\section{BACKGROUND}

Mortality from coronary heart disease (CHD) in developed nations has fallen over the past three decades; however, CHD still accounts for around $20 \%$ of deaths in Europe. ${ }^{1}$ In the UK, around 110000 men and 65000 women are admitted with acute coronary syndrome every year and it is estimated that there are 2.3 million people living with CHD. ${ }^{2}$

Cardiac rehabilitation (CR) is offered to individuals after cardiac events in order to facilitate recovery and prevent relapse by optimising cardiovascular risk reduction, fostering healthy behaviours and compliance to these behaviours, and promoting an active lifestyle. ${ }^{3}$ While a central component is exercise training, ${ }^{4}{ }^{5}$ it is recommended that CR programmes provide lifestyle education on CHD risk factor management plus counselling and psychological support-so-called 'comprehensive CR'. ${ }^{6} 7$ Such programmes are designed to limit the physiological and psychological effects of cardiac illness, reduce the risk for sudden death or reinfarction following myocardial infarction (MI), control cardiac symptoms, stabilise or reverse the atherosclerotic process, and enhance the psychosocial and vocational status of selected patients (eg, by improving functional capacity to support early return to work ${ }^{7}$ ).

Recent Cochrane reviews demonstrate that CR improves health-related quality of life (HRQoL) and reduces hospital admissions compared with usual care in various patient groups including those with MI, heart failure and following percutaneous coronary intervention and coronary artery bypass graft. $^{8} \quad 9$ National and international professional guidelines including the National Institute for Health and Care Excellence (NICE) in the UK, the American Heart Association/ American College of Cardiology, and the European Society of Cardiology recommend CR as an effective and safe intervention in the management of CHD and heart failure. ${ }^{10-15}$

Despite these apparent benefits and recommendations, participation in $\mathrm{CR}$ in the UK and abroad remains suboptimal, particularly for heart failure. ${ }^{16}{ }^{17}$ A 2012 UK-based 
survey found that only $16 \%$ of CR centres provided a programme specifically designed for people with heart failure; commonly cited reasons for the lack of provision of CR were a lack of resources and exclusion from commissioning agreements. ${ }^{16}$ Two main reasons given by patients for failing to take part in CR are difficulties with regular attendance at their local hospital and reluctance to join group-based classes. ${ }^{18}$

Home-based rehabilitation programmes have been introduced as an alternative to the conventional centrebased CR to widen access and participation. For example, the Heart Manual (developed by National Health Service (NHS) Lothian) is a self-help manual supported by a trained professional, which is designed to assist in recovery and improve patients' understanding and management of their condition following MI, and is now widely used in the UK, Italy, Canada, Australia and New Zealand. ${ }^{19} 20$

While the previous Cochrane review found homebased and centre-based CR programmes to be equally effective in improving participant outcomes, ${ }^{21}{ }^{22}$ the majority of evidence was in low-risk patients following MI or revascularisation. We are aware of a number of randomised head-to-head trials of centre-based versus homebased CR in heart failure that have been published since the previous review. ${ }^{23-25}$

The aim of this study was to update the previous (2010) Cochrane systematic review and meta-analysis of the randomised controlled trial evidence comparing home-based and centre-based CR.

\section{METHODS}

We conducted and reported this systematic review in accordance with the PRISMA (Preferred Reporting Items for Systematic Reviews and Meta-Analyses) statement. ${ }^{26}$

\section{Search methods for identification of studies}

The search strategy was designed in accordance with the previous Cochrane review and used both controlled vocabulary (eg, Medical Subject Headings (MeSH)) and key words ('heart disease and (synonym)' and 'rehabilitation or exercise or (synonym)') combined with a randomised controlled trial filter. ${ }^{21}$ The list of studies was updated with electronic searches of the Cochrane Central Register of Controlled Trials (CENTRAL), MEDLINE, EMBASE, PsycINFO and CINAHL plus (see online supplementary material file, eg). Databases were searched from January 2008 (end date of previous review) to October 2014, with no language or other restrictions. Trial registers (controlled-trials.com and clinicaltrials.gov) were also checked, in addition to reference lists of all eligible studies and other published systematic reviews.

\section{Study selection}

We included randomised trials (individual or cluster) directly comparing home-based versus centre-based CR.
The study population included adults with MI, angina pectoris or heart failure, or who had undergone coronary revascularisation (coronary artery bypass grafting, percutaneous transluminal coronary angioplasty or coronary artery stenting).

Home-based CR was defined as a structured programme with clear objectives for the participants, including monitoring, follow-up visits, letters or telephone calls from staff or at least self-monitoring diaries. ${ }^{27}$ Centrebased CR was a supervised group-based programme undertaken in a hospital or community setting (eg, gym or sports centre). We included exercise-only and comprehensive CR programmes.

Studies with one or more of the following outcome measures were included: mortality (cardiac and overall); morbidity (reinfarction, revascularisation or cardiac-related hospitalisation); exercise capacity; modifiable coronary risk factors (ie, smoking, blood lipid levels and blood pressure); HRQoL; adverse events (withdrawal from the trial or exercise programme); health service use or costs; adherence to CR.

Selection of studies involved the initial screening of titles and abstracts, followed by an assessment of the fulltext reports of all potentially relevant trials. Two authors (RST, SGD or RJN) independently assessed trials for inclusion and where there was a disagreement, the opinion of a third author (RST, SGD or RJN) was sought.

\section{Data extraction and risk of bias assessment}

The following information categories were extracted: study design, participants (baseline characteristics), details of the intervention (including type, frequency, duration and intensity of exercise training and nature of co-interventions), length of follow-up and outcome results. We assessed study risk of bias using the Cochrane standard criteria ${ }^{28}$ (random sequence generation and allocation concealment, dropouts and withdrawals, outcome blinding, and selective reporting) and also balance of groups at baseline and use of intention-to-treat analysis. Data extraction and risk of bias assessment was carried out by a single reviewer (RJN) and checked by a second reviewer (SGD or RST). Where necessary, authors of included studies were contacted for further information. This included clarification of issues of study design to inform risk of bias assessment and outcomes (eg, missing SDs).

\section{Data analysis}

Data were analysed in accordance with the Cochrane Handbook. ${ }^{28}$ For dichotomous variables, relative risks (RRs) and 95\% CIs were calculated for each outcome, and for continuous variables, mean differences (MDs) and $95 \%$ CIs were calculated. Where differences between groups for each individual trial were not reported, we calculated $p$ values for the differences.

We explored heterogeneity among the included studies qualitatively (by comparing the study characteristics) and quantitatively (using the $\chi^{2}$ test of 
heterogeneity and $\mathrm{I}^{2}$ statistic). Where appropriate, an overall estimate of treatment effect was obtained by combining the results from included studies for each outcome. We employed a random-effects model where there was formal evidence of statistical heterogeneity $\left(\mathrm{I}^{2}>50 \%\right)$. For outcomes with lower levels of statistical heterogeneity, we applied both fixed and random models, reporting fixed-effects results unless there was a difference in statistical inference, where we reported the most conservative random-effects model.

Given the variety of outcome measures reported for exercise capacity, to allow us to pool findings across studies, between-group results for each study were expressed as a standardised MD (SMD). Miller et $a t^{29}$ included subgroups by duration of the intervention (11 or 26 weeks) and Gordon et $a l^{30}$ compared two homebased exercise groups with a centre-based programme. For these two studies, outcome results were reported separately for each comparison. Given the small number of studies, it was not possible to assess potential small study effects and publication bias using funnel plots and Egger tests ${ }^{31}$ with the exception of the outcome of exercise capacity. We undertook two subgroup analyses for exercise capacity: (1) comparison of trials of patients with heart failure versus other post-MI/revascularisation and (2) comparison of trials published before the year 2000 vs 2000 or later (to assess the impact of older trials in relation to advancement of medical technology, medications and interventional cardiology). Analyses were conducted using RevMan V.5.2.

\section{RESULTS}

\section{Study selection}

The previous Cochrane review provided 12 included studies (22 publications; JM Bell. A comparison of a multi-disciplinary home based cardiac rehabilitation programme with comprehensive conventional rehabilitation in post-myocardial infarction patients. [Thesis submitted to the University of London for the degree of Doctor of Philosophy]. 1998). ${ }^{29} 3032-40$ Our updated searches produced a total of 12949 titles from which an additional five studies (six publications) were included. ${ }^{23-25} 4142$ Outcomes of one previously included trial with a longer follow-up (18 months and 6 years postrandomisation) were also identified. ${ }^{32}{ }^{43}$ The study selection process is summarised in figure 1. Excluded studies and reasons for exclusion are shown in online supplementary table A.

The 17 studies of home-based versus centre-based CR included a total of 2172 patients in 10 countries from across four continents (see table 1). Most studies reported outcomes up to 12 months postrandomisation; three studies also reported a longer term follow-up. ${ }^{32} 3638$

The CR programmes differed considerably between studies in terms of duration (range 1.5-6 months), frequency (one to five sessions per week) and length (20-60 min per session). Eleven studies compared comprehensive programmes (ie, exercise plus education and/ or psychological management) while six reported only an exercise intervention. ${ }^{23} 2429353740$ Most programmes used individually tailored exercise prescriptions, making it difficult to precisely quantify the amount of exercise undertaken. Almost all home-based programmes were based on walking with intermittent support from a nurse or exercise specialist, while centre-based programmes typically provided a supervised cycle and treadmill exercise (see online supplementary table B).

Of the 13 studies that recruited patients following acute MI or coronary revascularisation, 12 of these included patients classed as 'low' or 'moderate' risk as defined by the American Association of Cardiovascular and Pulmonary Rehabilitation (AACVPR) guidelines for CR

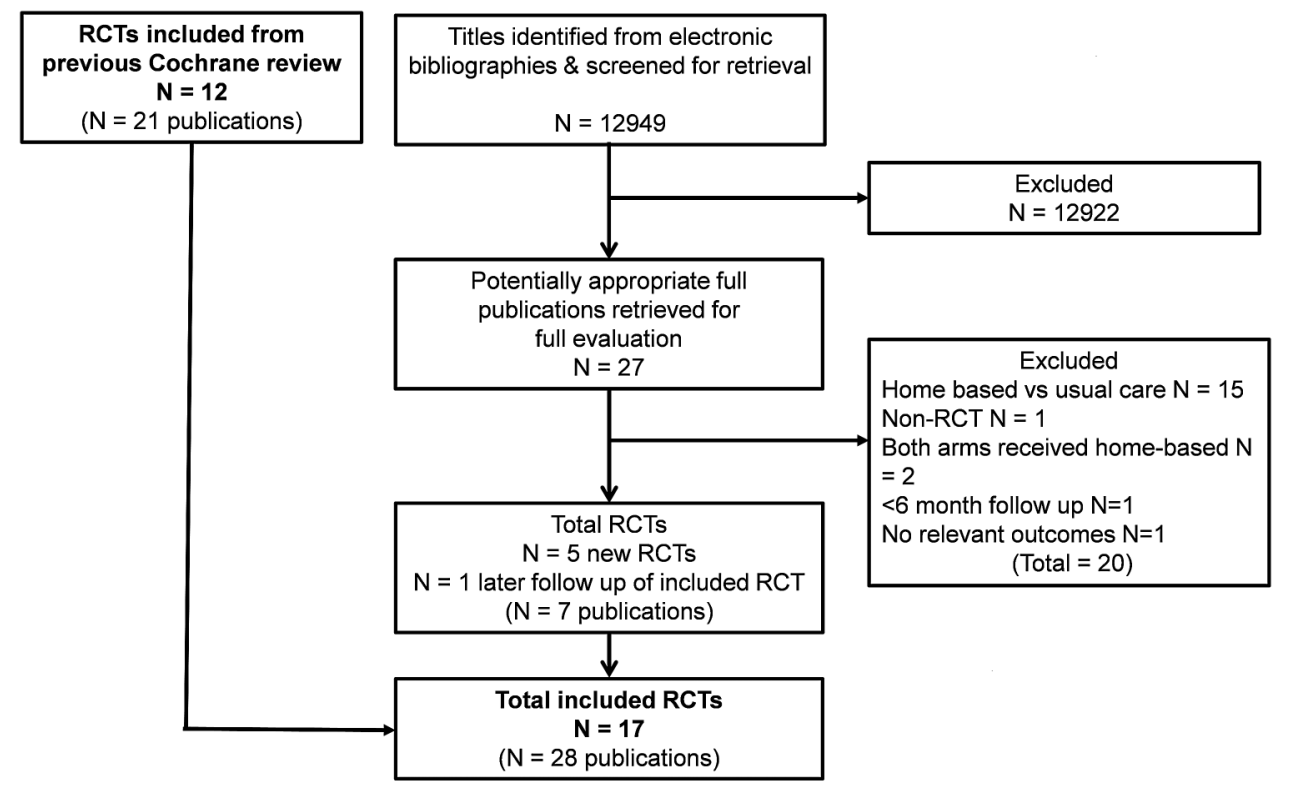

Figure 1 Summary of study selection process.RCT, randomised controlled trial. 


\begin{tabular}{|c|c|c|c|c|c|c|}
\hline Study & $\begin{array}{l}\text { Participants } \\
\text { (number and } \\
\text { diagnosis) }\end{array}$ & Interventions & Outcomes & Follow-up & Subgroup analyses & $\begin{array}{l}\text { Country/ } \\
\text { setting }\end{array}$ \\
\hline$\overline{\text { Arthur et } a \beta^{32}}$ & $\begin{array}{l}242 \text { post-CABG } \\
\text { surgery }\end{array}$ & $\begin{array}{l}\text { Home-based vs } \\
\text { centre-based }\end{array}$ & $\begin{array}{l}\text { Primary: exercise capacity (METs). } \\
\text { Secondary: HRQoL (SF-36), cardiac } \\
\text { morbidity, mortality }\end{array}$ & $\begin{array}{l}6 \text { and } 18 \text { months and } \\
6 \text { years } \\
\text { postrandomisation }\end{array}$ & None & $\begin{array}{l}\text { Canada, } \\
\text { single } \\
\text { centre }\end{array}$ \\
\hline $\begin{array}{l}\text { Bell (JM Bell. } \\
\text { Thesis submitted } \\
\text { to the University } \\
\text { of London for the } \\
\text { degree of Doctor } \\
\text { of Philosophy. } \\
\text { 1998) }\end{array}$ & 252 post-MI & $\begin{array}{l}\text { Home-based } \\
\text { (Heart Manual) vs } \\
\text { centre-based }\end{array}$ & $\begin{array}{l}\text { Primary: exercise capacity (METs) } \\
\text { Secondary: total cholesterol, systolic } \\
\text { blood pressure, HRQoL (NHP), } \\
\text { smoking, mortality, readmission rate, } \\
\text { use of primary care services }\end{array}$ & $\begin{array}{l}16 \text { and } 48 \text { weeks } \\
\text { postrandomisation } \\
(20 \text { and } 50 \text { weeks } \\
\text { post-MI) }\end{array}$ & None & $\begin{array}{l}\text { UK, } 5 \\
\text { district } \\
\text { hospitals }\end{array}$ \\
\hline Carlson et $a{ }^{\beta 3}$ & $\begin{array}{l}80 \text { coronary artery } \\
\text { bypass, angioplasty, } \\
\text { MI, angiographically } \\
\text { confirmed CHD }\end{array}$ & $\begin{array}{l}\text { Home-based vs } \\
\text { centre-based }\end{array}$ & $\begin{array}{l}\text { Primary: peak functional capacity } \\
\text { (METs), LDL cholesterol } \\
\text { Secondary. total cholesterol, HDL } \\
\text { cholesterol, triglycerides, blood } \\
\text { pressure, cardiovascular medications, } \\
\text { costs, adherence (exercise sessions } \\
\text { attended) }\end{array}$ & $\begin{array}{l}6 \text { months } \\
\text { postrandomisation }\end{array}$ & None & $\begin{array}{l}\text { USA, } \\
\text { single } \\
\text { hospital } \\
\text { centre }\end{array}$ \\
\hline Cowie et $a f^{3}$ & $\begin{array}{l}60 \mathrm{NYHA} \text { class II/III } \\
\text { patients with post-HF }\end{array}$ & $\begin{array}{l}\text { Home-based vs } \\
\text { centre-based vs } \\
\text { usual care control }\end{array}$ & $\begin{array}{l}\text { Exercise capacity (shuttle walk test), } \\
\text { HFQoL (SF-36 and MLHFQ) }\end{array}$ & 8 weeks & None & $\begin{array}{l}\text { UK, single } \\
\text { centre }\end{array}$ \\
\hline Dalal et $a{ }^{\beta 4}$ & 104 post-MI & $\begin{array}{l}\text { Home-based } \\
\text { (Heart Manual) vs } \\
\text { centre-based }\end{array}$ & $\begin{array}{l}\text { Primary: quality of life (MacNew } \\
\text { questionnaire), total cholesterol } \\
\text { Secondary: exercise capacity (METs), } \\
\text { self-reported smoking, cardiovascular } \\
\text { morbidity, mortality, secondary } \\
\text { prevention medication use }\end{array}$ & $\begin{array}{l}9 \text { months } \\
\text { postrandomisation }\end{array}$ & None & $\begin{array}{l}\text { UK, single } \\
\text { centre }\end{array}$ \\
\hline Daskapan et $a^{\beta 5}$ & 29 patients with HF & $\begin{array}{l}\text { Home-based vs } \\
\text { centre-based }\end{array}$ & $\begin{array}{l}\text { Exercise capacity }(\mathrm{mL} / \mathrm{kg} / \mathrm{min}) \text {, resting } \\
\text { blood pressure, systolic and diastolic } \\
\text { blood pressure, adherence, dropouts, } \\
\text { mortality }^{*}\end{array}$ & $\begin{array}{l}12 \text { weeks } \\
\text { postrandomisation }\end{array}$ & None & $\begin{array}{l}\text { Turkey, } \\
\text { single } \\
\text { centre }\end{array}$ \\
\hline Gordon et $a^{\beta 0}$ & $\begin{array}{l}155 \text { coronary artery } \\
\text { disease (Ml and/or } \\
\text { CABG and/or PTCA } \\
\text { and/or chronic stable } \\
\text { angina) }\end{array}$ & $\begin{array}{l}\text { Supervised home } \\
\text { vs community } \\
\text { home vs } \\
\text { centre-based }\end{array}$ & $\begin{array}{l}\text { Maximal oxygen uptake, blood } \\
\text { pressure, fasting serum lipids, } \\
\text { self-reported smoking status, } \\
\text { rehospitalisation, adherence } \\
\text { (completion of appointments) }\end{array}$ & $\begin{array}{l}12 \text { weeks } \\
\text { postrandomisation }\end{array}$ & $\begin{array}{l}\text { Changes reported for all } \\
\text { patients and for patients } \\
\text { with baseline values } \\
\text { defined as abnormal }\end{array}$ & $\begin{array}{l}\text { USA, } \\
\text { single } \\
\text { centre }\end{array}$ \\
\hline
\end{tabular}




\begin{tabular}{|c|c|c|c|c|c|c|}
\hline Study & $\begin{array}{l}\text { Participants } \\
\text { (number and } \\
\text { diagnosis) } \\
\end{array}$ & Interventions & Outcomes & Follow-up & Subgroup analyses & $\begin{array}{l}\text { Country/ } \\
\text { setting }\end{array}$ \\
\hline Jolly et $a{ }^{\beta 6}$ & $\begin{array}{l}525 \text { patients with } \\
\text { post-MI, post-PTCA } \\
\text { and post-CABG }\end{array}$ & $\begin{array}{l}\text { Home-based } \\
\text { (Heart Manual) vs } \\
\text { centre-based }\end{array}$ & $\begin{array}{l}\text { Primary: serum cholesterol, total } \\
\text { cholesterol, HDL cholesterol, blood } \\
\text { pressure, exercise capacity (ISWT), } \\
\text { smoking (cotinine-validated) } \\
\text { Secondary: quality of life (EQ-5D), } \\
\text { health service usage (hospital } \\
\text { readmissions, primary care visits, } \\
\text { medication), mortality, cardiovascular } \\
\text { events, costs }\end{array}$ & 6,12 and 24 months & $\begin{array}{l}\text { Yes-'interaction terms } \\
\text { between these factors } \\
\text { (diagnosis (MI/ } \\
\text { revascularisation), age, sex } \\
\text { and ethnicity) and } \\
\text { rehabilitation setting were } \\
\text { included to investigate } \\
\text { possible differences in } \\
\text { treatment effect between } \\
\text { subgroups of patients'. }\end{array}$ & $\begin{array}{l}\text { UK, } 4 \\
\text { hospital } \\
\text { centres }\end{array}$ \\
\hline Karapolat et $a^{24}$ & 74 patients with HF & $\begin{array}{l}\text { Home-based vs } \\
\text { centre-based }\end{array}$ & $\begin{array}{l}\text { Exercise capacity, quality of life } \\
(\mathrm{SF}-36)^{\star}\end{array}$ & 8 weeks & None & $\begin{array}{l}\text { Turkey, } \\
\text { single } \\
\text { centre }\end{array}$ \\
\hline Kassaian et $a \beta^{\beta 7}$ & $\begin{array}{l}125 \text { patients with } \\
\text { post-MI and/or } \\
\text { post-CABG }\end{array}$ & $\begin{array}{l}\text { Home-based vs } \\
\text { centre-based }\end{array}$ & $\begin{array}{l}\text { Systolic and diastolic blood pressure, } \\
\text { heart rate (all resting and submaximal), } \\
\text { functional capacity (METs), BMI, } \\
\text { cholesterol (total, LDL, HDL, } \\
\text { triglyceride) }\end{array}$ & $\begin{array}{l}12 \text { weeks } \\
\text { postrandomisation }\end{array}$ & $\begin{array}{l}\text { Comparison of functional } \\
\text { capacity, submaximal } \\
\text { systolic blood pressure, } \\
\text { diastolic blood pressure, } \\
\text { and heart rate in patients } \\
\text { with left ventricular } \\
\text { dysfunction vs good } \\
\text { function }\end{array}$ & $\begin{array}{l}\text { Iran, single } \\
\text { centre }\end{array}$ \\
\hline $\begin{array}{l}\text { Marchionni } \\
\text { et } a \beta^{\beta 8}\end{array}$ & $\begin{array}{l}180 \text { patients with } \\
\text { post-MI }\end{array}$ & $\begin{array}{l}\text { Home-based vs } \\
\text { centre-based }\end{array}$ & $\begin{array}{l}\text { Primary: TWC } \\
\text { Secondary: HRQoL (SIP), mortality, } \\
\text { morbidity (cardiovascular events), } \\
\text { healthcare usage (medical visits, } \\
\text { rehospitalisations), costs, adherence } \\
\text { (number of completed training } \\
\text { sessions) }\end{array}$ & $\begin{array}{l}2,8 \text { and } 14 \text { months } \\
\text { postrandomisation }\end{array}$ & $\begin{array}{l}\text { Subgroup analysis by age } \\
\text { (years)-middle-aged (45- } \\
65), \text { old }(65-75) \text {, very old } \\
(>75)\end{array}$ & $\begin{array}{l}\text { Italy, single } \\
\text { hospital } \\
\text { centre }\end{array}$ \\
\hline Miller et $a{ }^{29}$ & $\begin{array}{l}127 \text { patients with } \\
\text { post-MI }\end{array}$ & $\begin{array}{l}\text { Home-based vs } \\
\text { centre-based }\end{array}$ & $\begin{array}{l}\text { Exercise capacity, mortality, } \\
\text { cardiovascular morbidity }^{*}\end{array}$ & $\begin{array}{l}23 \text { weeks } \\
\text { postrandomisation }\end{array}$ & $\begin{array}{l}\text { Results reported according } \\
\text { to } 2 \text { subgroups-brief vs } \\
\text { extended exercise training }\end{array}$ & $\begin{array}{l}\text { USA, } \\
\text { single } \\
\text { hospital } \\
\text { centre }\end{array}$ \\
\hline Moholdt et $a l^{41}$ & $\begin{array}{l}30 \text { patients with } \\
\text { post-CABG }\end{array}$ & $\begin{array}{l}\text { Home-based vs } \\
\text { centre-based } \\
\text { (residential } \\
\text { rehabilitation) }\end{array}$ & $\begin{array}{l}\text { Primary: peak oxygen consumption } \\
\text { Secondary: HRQoL, cholesterol (total, } \\
\text { HDL and triglycerides) }\end{array}$ & $\begin{array}{l}6 \text { months } \\
\text { postrandomisation }\end{array}$ & None & $\begin{array}{l}\text { Norway, } \\
\text { single } \\
\text { hospital } \\
\text { centre }\end{array}$ \\
\hline Oerkild et $a f^{42}$ & $\begin{array}{l}75 \text { coronary heart } \\
\text { disease (acute MI, } \\
\text { PTCA or CABG) }\end{array}$ & $\begin{array}{l}\text { Home-based vs } \\
\text { centre-based }\end{array}$ & $\begin{array}{l}\text { Primary: exercise capacity }\left(\mathrm{VO}_{2} \text { and }\right. \\
6 \mathrm{MWT}) \\
\text { Secondary: systolic and diastolic blood } \\
\text { pressure, cholesterol (total, } \mathrm{HDL} \text { and } \\
\text { LDL), smoking, HRQL (SF-12) }\end{array}$ & 3 and 12 months & None & $\begin{array}{l}\text { Denmark, } \\
\text { single } \\
\text { centre }\end{array}$ \\
\hline
\end{tabular}




\begin{tabular}{|c|c|c|c|c|c|c|}
\hline Study & $\begin{array}{l}\text { Participants } \\
\text { (number and } \\
\text { diagnosis) }\end{array}$ & Interventions & Outcomes & Follow-up & Subgroup analyses & $\begin{array}{l}\text { Country/ } \\
\text { setting }\end{array}$ \\
\hline Piotrowicz et a P5 $^{5}$ & $\begin{array}{l}152 \text { patients with HF } \\
\text { (NYHA class II and } \\
\text { III) }\end{array}$ & $\begin{array}{l}\text { Home-based } \\
\text { (telemonitored) vs } \\
\text { centre-based } \\
\text { (outpatient) }\end{array}$ & $\begin{array}{l}\text { Exercise capacity (6MWT), quality of } \\
\text { life (SF-36), mortality, hospitalisation* }\end{array}$ & 8 weeks & None & $\begin{array}{l}\text { Poland, } \\
\text { single } \\
\text { centre }\end{array}$ \\
\hline Sparks et $\left.a\right|^{\beta 9}$ & $\begin{array}{l}20 \text { post-MI, PTCA or } \\
\text { CABG }\end{array}$ & $\begin{array}{l}\text { Home-based vs } \\
\text { centre-based }\end{array}$ & $\begin{array}{l}\text { Exercise capacity (peak } \mathrm{VO}_{2} \text { max), } \\
\text { adherence (compliance with exercise), } \\
\text { safety (dropout)* }\end{array}$ & $\begin{array}{l}12 \text { weeks } \\
\text { postrandomisation }\end{array}$ & None & $\begin{array}{l}\text { USA, } \\
\text { single } \\
\text { hospital } \\
\text { centre }\end{array}$ \\
\hline Wu et $a l^{40}$ & $\begin{array}{l}36 \text { patients with } \\
\text { post-CABG }\end{array}$ & $\begin{array}{l}\text { Home-based vs } \\
\text { centre-based }\end{array}$ & Exercise capacity (METs) ${ }^{*}$ & $\begin{array}{l}12 \text { weeks } \\
\text { postrandomisation }\end{array}$ & None & $\begin{array}{l}\text { Taiwan } \\
\text { (China), } \\
\text { single } \\
\text { centre }\end{array}$ \\
\hline
\end{tabular}

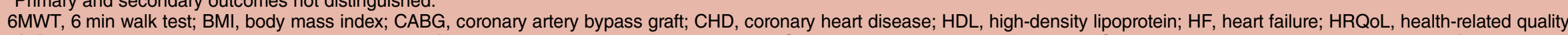
of life; LDL, low-density lipoprotein; MI, myocardial infarction; MET, metabolic equivalent; MLHFQ, Minnesota Living with Heart Failure Questionnaire; NHP, Nottingham Health Profile; NYHA,

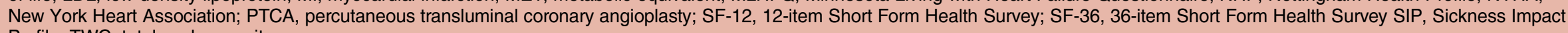

Profile; TWC, total work capacity.

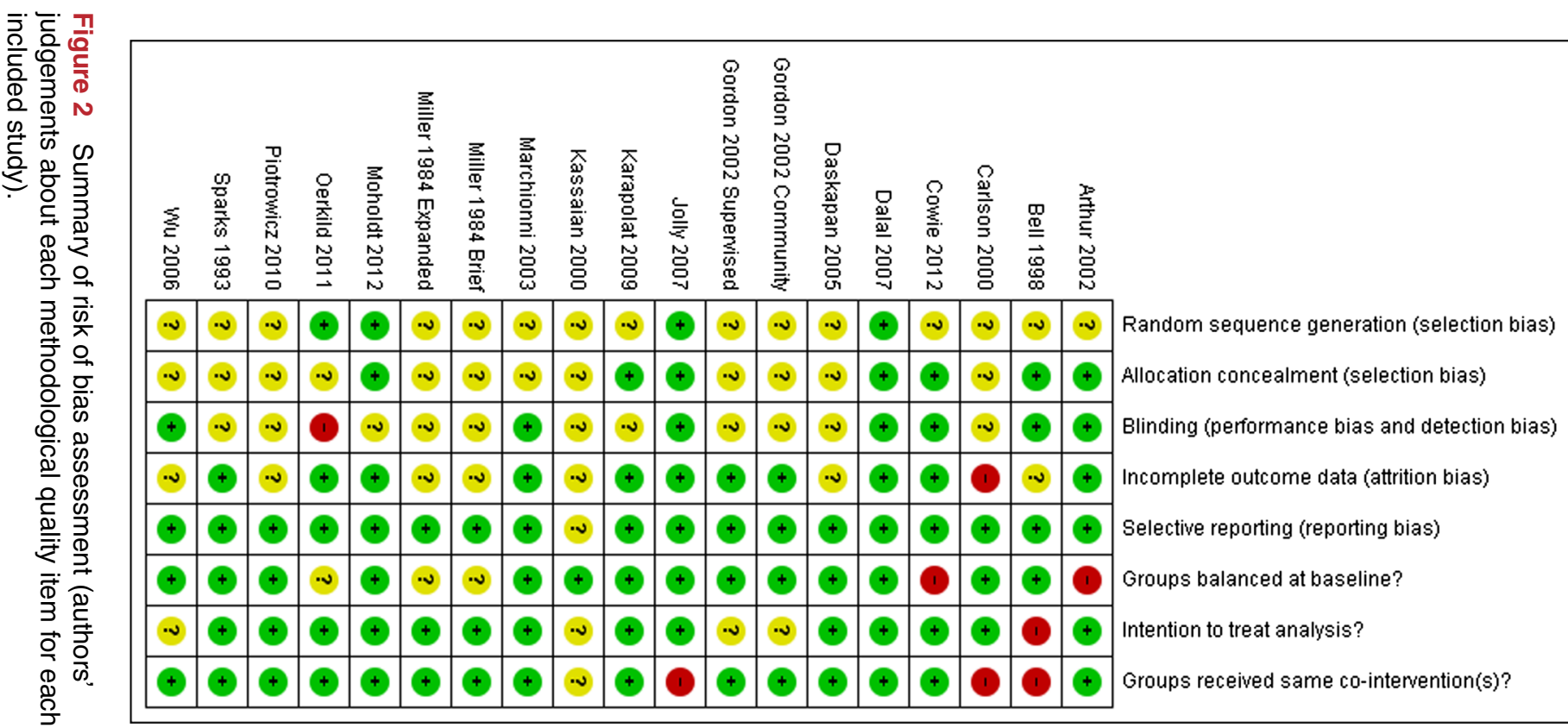

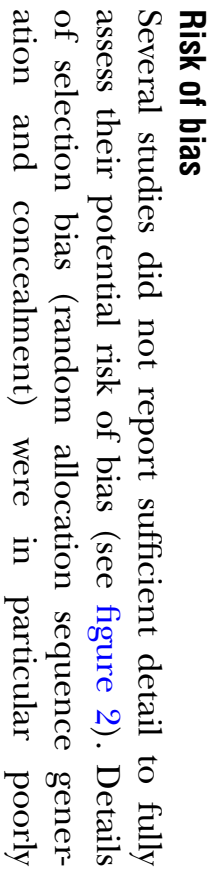




reported. However, only two studies presented objective evidence of imbalances in baseline patient characteristics. ${ }^{23}{ }^{32}$ Given the nature of the CR intervention, it is not possible to blind the patients or clinicians to group allocation; in such situations, blinding outcome assessors to knowledge of allocation is probably of greater importance. Only seven studies stated that they took measures to blind outcome assessment (JM Bell. Thesis submitted to the University of London for the degree of Doctor of Philosophy. 1998). ${ }^{23} 3234363840$ Although the type of analysis was often not stated, all studies appeared to undertake an intention-to-treat analysis (ie, groups were compared according to initial random allocation). Loss to follow-up or dropout appeared to vary considerably across studies and was often asymmetric between homebased and centre-based groups. Although it was difficult to quantify the precise level of CR intervention delivered (due to the individually tailored nature of many programmes), the intensity of the rehabilitation programme seemed to differ substantially between the home-based and centre-based arms. The majority of trials were judged to be of low risk of bias in terms of selective reporting and whether groups received the same co-interventions.

\section{Effects of interventions}

Clinical events: mortality and morbidity

All-cause mortality up to 1 year of follow-up was reported in 8 of the 17 studies (JM Bell. Thesis submitted to the University of London for the degree of Doctor of Philosophy. 1998). ${ }^{25} 29$ 34-36 4142 A pooled analysis of these studies (excluding Miller $e t a l,{ }^{29}$ who reported no deaths) found no difference in mortality at 3-12 months of follow-up between the home-based and centre-based CR groups (see online supplementary figure A). The study of Jolly $e t a l^{6}$ found no significant between-group difference at 24 months.

Only four studies reported cardiac events. Dalal $e t a l^{34}$ and Jolly $e t a l^{36}$ found no significant difference in coronary revascularisation or recurrent MI events between home-based and centre-based CR, and Piotrowicz et $a l^{25}$ reported no heart failure-related admissions in either group. Oerkild et a $t^{42}$ did not report numbers of events but stated that there were no between-group differences in the number and length of admissions and adverse events including MI, progressive angina, decompensated congestive heart failure, severe bleeding, new malignant disease and performance of percutaneous coronary intervention. In the 6-year follow-up of the study by Arthur et $a l^{32}{ }^{43}$ the total number of hospitalisations (cardiac and non-cardiac) was greater in centre-based patients with CR than in the home-based group (79 vs 42, $\mathrm{p}<0.0001)$.

\section{Exercise capacity}

All 17 included studies reported on exercise capacity in the short term ( $\leq 12$ months' follow-up) and 3 reported longer term data (>12 months). ${ }^{32} \quad 36 \quad 38$ Measures of exercise capacity included peak oxygen uptake, walking distance and workload on a static cycle.

Pooled analysis of all studies showed no difference in short-term exercise capacity between the home-based and centre-based CR (random-effects SMD -0.10, 95\% CI -0.29 to $0.08, \mathrm{I}^{2} 72 \%$; see table 2 and figure $3 \mathrm{~A}$ ). Similarly, pooled analysis of the studies with $>12$ months' follow-up showed that there was no evidence of an overall difference in exercise capacity between the two groups in the longer term (fixed-effects SMD 0.11, 95\% CI -0.01 to $0.23, \mathrm{I}^{2} 0 \%$; see table 2 and figure $3 \mathrm{~B}$ ). Arthur et $a \vec{l}^{2}$ found that mean peak oxygen consumption at 6-year follow-up was higher $(p=0.01)$ in the home-based CR group $(1543 \mathrm{~mL} / \mathrm{min})$ than for those who received centre-based CR $(1412 \mathrm{~mL} / \mathrm{min})$.

There was no evidence of subgroup difference in the difference in exercise capacity between home-based and centre-based CR comparing two groups of trials: (1) trials in heart failure versus trials in post-MI/revascularisation (subgroup $\mathrm{p}=0.74$ ); (2) trials published before 2000 versus trials in 2000 or later (subgroup $\mathrm{p}=0.59$ ).

\section{Modifiable cardiovascular risk factors}

Eight trials assessed systolic and diastolic blood pressure $^{30} 33-3742$ or systolic blood pressure alone (JM Bell. Thesis submitted to the University of London for the degree of Doctor of Philosophy. 1998), with absolute values at follow-up reported by all but two studies ${ }^{30} 42$ which reported change from baseline instead. Pooled analysis showed no difference in systolic blood pressure between home-based and centre-based patients with CR at follow-up (random-effects MD $0.2 \mathrm{~mm} \mathrm{Hg}, 95 \%$ CI -3.4 to $3.8, \mathrm{I}^{2} 65 \%$; see table 2 , online supplementary figure B). Diastolic blood pressure was slightly lower following centre-based CR compared with home-based CR (fixed-effects $\mathrm{MD}<-1.9 \mathrm{~mm} \mathrm{Hg}, 95 \%$ CI -0.8 to $-3.0, \mathrm{I}^{2} 37 \%$; $\mathrm{p}=0.009$; see table 2 , online supplementary figure $\mathrm{C}$ ). At 24 months' follow-up, Jolly et $a l^{36}$ reported no difference in either systolic (MD $0.85 \mathrm{~mm} \mathrm{Hg}, 95 \%$ CI -2.5 to 4.2 ) or diastolic (MD $0.8 \mathrm{~mm} \mathrm{Hg}, 95 \%$ CI -1.1 to 2.6) blood pressure between the home-based and centre-based groups.

Of the eight trials reporting data on blood lipids, all reported total cholesterol values (JM Bell. Thesis submitted to the University of London for the degree of Doctor of Philosophy. 1998),,$^{30} \quad \begin{array}{lllllll}33 & 34 & 36 & 37 & 41 & 42 & \text { six }\end{array}$ reported high-density lipoprotein (HDL) concentrations $^{30} 33 \quad 36374142$ and four reported low-density lipoprotein (LDL) cholesterol and triglycerides. ${ }^{30} 33 \quad 3742$ Meta-analysis found no evidence of a difference between the home-based and centre-based groups in terms of total cholesterol (random-effects $\mathrm{MD}-0.07 \mathrm{mmol} / \mathrm{L}$, $95 \%$ CI -0.24 to $0.11, \mathrm{I}^{2} 62 \%$ ), LDL (random-effects $\mathrm{MD}-0.06 \mathrm{mmol} / \mathrm{L}, 95 \% \mathrm{CI}-0.27$ to $0.15, \mathrm{I}^{2} 62 \%$ ) or triglyceride (random-effects $\mathrm{MD}-0.16 \mathrm{mmol} / \mathrm{L}, 95 \% \mathrm{CI}$ -0.38 to $0.07, \mathrm{I}^{2} 47 \%$ ) concentrations at $3-12$ months' follow-up (see table 2, online supplementary figures D, F and $\mathrm{G})$. There was some evidence of a lower HDL 
Table 2 Summary of the effects of home-based versus centre-based cardiac rehabilitation

\begin{tabular}{|c|c|c|c|c|c|c|c|c|}
\hline \multirow[b]{2}{*}{$\begin{array}{l}\text { Outcome or } \\
\text { subgroup }\end{array}$} & \multirow[b]{2}{*}{$\begin{array}{l}\text { Number of } \\
\text { studies }\end{array}$} & \multirow[b]{2}{*}{$\begin{array}{l}\text { Number of } \\
\text { participants }\end{array}$} & \multirow[b]{2}{*}{$\begin{array}{l}\text { Summary estimate } \\
\text { and model }\end{array}$} & \multirow{2}{*}{$\begin{array}{l}\text { Effect estimate } \\
(95 \% \mathrm{Cl}) \text { with } p \text { values } \\
\text { where significant }\end{array}$} & \multicolumn{4}{|c|}{ Heterogeneity } \\
\hline & & & & & $\chi^{2}$ & d.f. & p Value & $\mathrm{I}^{2}(\%)$ \\
\hline \multicolumn{9}{|l|}{ Exercise capacity } \\
\hline $\begin{array}{l}\leq 12 \text {-month } \\
\text { follow-up }\end{array}$ & 19 & 1876 & $\begin{array}{l}\text { Standard mean } \\
\text { difference, } \\
\text { random-effects model }\end{array}$ & $-0.10(-0.29$ to 0.08$)$ & 63.30 & 18 & $<0.00001$ & 72 \\
\hline $\begin{array}{l}\text { 12-24-month } \\
\text { follow-up }\end{array}$ & 3 & 1074 & $\begin{array}{l}\text { Standard mean } \\
\text { difference, } \\
\text { fixed-effects model }\end{array}$ & $0.11(-0.01$ to 0.23$)$ & 0.97 & 2 & 0.62 & 0 \\
\hline \multicolumn{9}{|c|}{ Blood pressure $(\mathrm{mm} \mathrm{Hg})$ at 3-12-month follow-up } \\
\hline Systolic & 9 & 1117 & $\begin{array}{l}\text { Mean difference, } \\
\text { random-effects model }\end{array}$ & $0.19(-3.37$ to 3.75$)$ & 23.07 & 8 & 0.003 & 65 \\
\hline Diastolic & 8 & 991 & $\begin{array}{l}\text { Mean difference, } \\
\text { fixed-effects model }\end{array}$ & $\begin{array}{l}-1.86(-2.95 \text { to }-0.76) \\
\text { lower in centre-based } \\
\text { group }(p=0.009)\end{array}$ & 11.12 & 7 & 0.13 & 37 \\
\hline \multicolumn{9}{|c|}{ Cholesterol (mmol/L) at 3-12-month follow-up } \\
\hline Total & 9 & 1109 & $\begin{array}{l}\text { Mean difference, } \\
\text { random-effects model }\end{array}$ & $-0.07(-0.24$ to 0.11$)$ & 20.98 & 8 & 0.007 & 62 \\
\hline HDL & 7 & 883 & $\begin{array}{l}\text { Mean difference, } \\
\text { fixed-effects model }\end{array}$ & $\begin{array}{l}-0.07(-0.11 \text { to }-0.03) \\
\text { lower in centre-based } \\
\text { group }(p=0.001)\end{array}$ & 10.49 & 6 & 0.11 & 43 \\
\hline LDL & 5 & 388 & $\begin{array}{l}\text { Mean difference, } \\
\text { random-effects model }\end{array}$ & $-0.06(-0.27$ to 0.15$)$ & 10.60 & 4 & 0.03 & 62 \\
\hline Triglycerides & 5 & 354 & $\begin{array}{l}\text { Mean difference, } \\
\text { random-effects model }\end{array}$ & $-0.16(-0.38$ to 0.07$)$ & 7.59 & 4 & 0.11 & 47 \\
\hline $\begin{array}{l}\text { Smoking (3- } \\
12 \text { months) }\end{array}$ & 6 & 986 & $\begin{array}{l}\text { Relative risk, } \\
\text { fixed-effects model }\end{array}$ & $0.98(0.79$ to 1.21$)$ & 4.48 & 5 & 0.48 & 0 \\
\hline Completers & 18 & 1984 & $\begin{array}{l}\text { Risk ratio, fixed-effects } \\
\text { model }\end{array}$ & $\begin{array}{l}1.04(1.01 \text { to } 1.07) \\
\text { higher completion in } \\
\text { home-based group } \\
(p=0.009)\end{array}$ & 30.26 & 17 & 0.02 & 44 \\
\hline Mortality & 7 & 1166 & $\begin{array}{l}\text { Relative risk, } \\
\text { fixed-effects model }\end{array}$ & $0.79(0.43$ to 1.47$)$ & 1.60 & 5 & 0.90 & 0 \\
\hline
\end{tabular}

concentration following centre-based CR (random-effects $\mathrm{MD}-0.07 \mathrm{mmol} / \mathrm{L}, 95 \%$ CI -0.03 to $-0.11, \mathrm{I}^{2} 43 \%$; $\mathrm{p}=0.001$; see table 2 , online supplementary figure $\mathrm{E}$ ), but the difference in HDL level was not sustained at 24 months' follow-up. ${ }^{36}$

A consistent reduction in self-reported smoking behaviour was found in the five studies that reported this outcome for the home-based and centre-based CR arms (JM Bell. Thesis submitted to the University of London for the degree of Doctor of Philosophy. 1998)..$^{30} 343642$ The proportion of smokers at follow-up in the centrebased group was similar to that in the home-based group after 3-12 months (fixed-effects RR 0.98 , 95\% CI 0.79 to $1.21, \mathrm{I}^{2} 0 \%$; see table 2 , online supplementary figure $\mathrm{H}$ ) and 24 months ( $\mathrm{RR}=1.16,95 \%$ CI 0.58 to 33.3$).{ }^{36}$

Health-related quality of life

Pooling of HRQoL outcomes was considered inappropriate due to the wide variation of measures used and instead results were compared across studies and tabulated (see table 3). Ten studies reported validated HRQoL measures including four generic measures (EQ-5D, Nottingham Health Profile, 36-item Short Form Health Survey (SF-36) and Sickness Impact Profile) and one disease-specific instrument (MacNew). From individual findings, there was no strong evidence of differences in overall HRQoL outcomes or domain scores at follow-up between home-based and centre-based CR. All studies reported improvements in HRQoL from baseline to follow-up, with the exception of two studies that used the EQ-5D where there were no changes in either the home-based or centre-based groups. ${ }^{34} 36$

\section{Withdrawals and adherence}

There was inconsistent reporting of dropout rates from the intervention, and reasons for withdrawal were often unclear. Using the number of completers (ie, the number of patients with outcome data at follow-up), we found some evidence of a small increase in the completion rate in the home-based compared with the centre- 
A

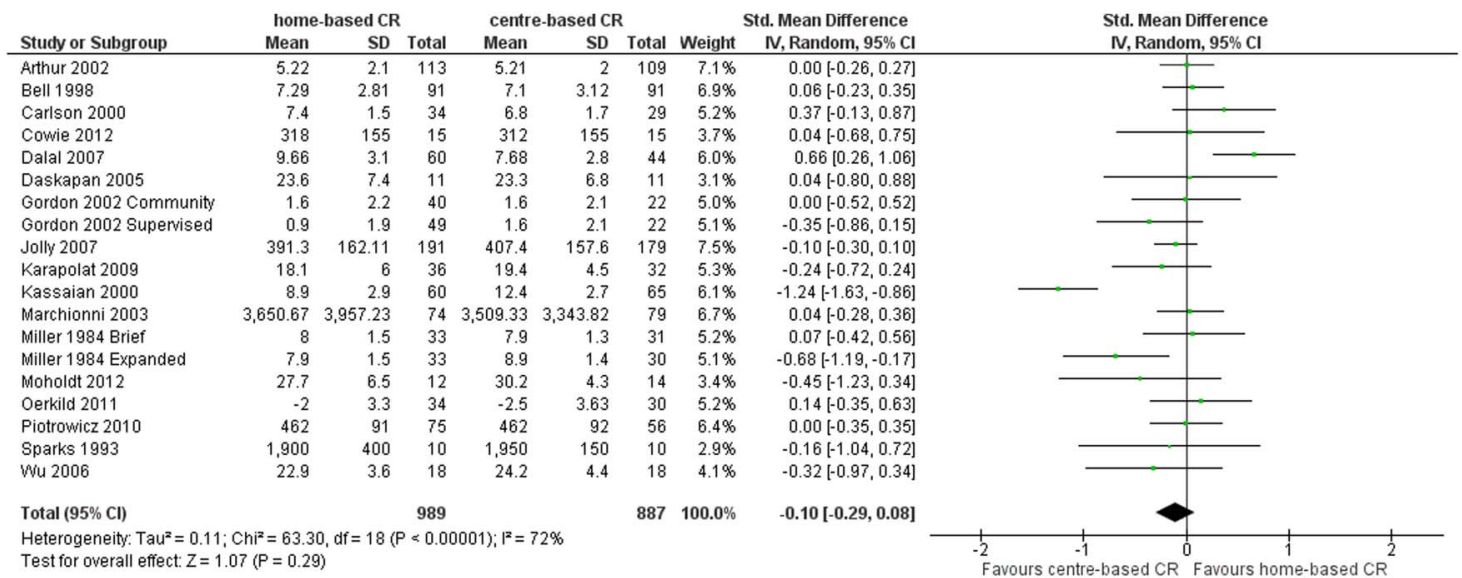

B

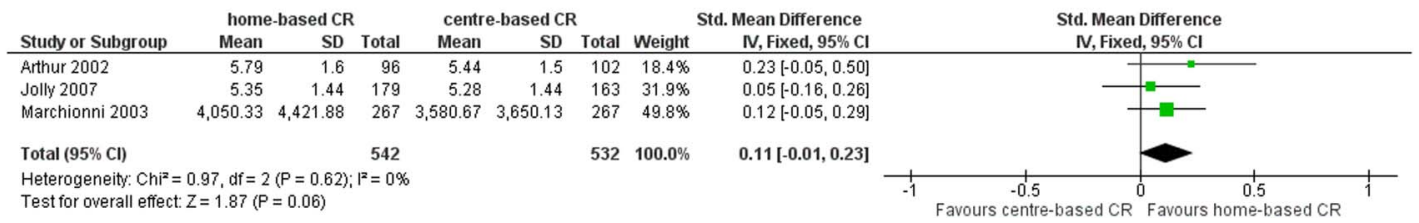

Figure 3 (A) Exercise capacity with home-based and centre-based CR at $\leq 12$ months' follow-up. (B) Exercise capacity with home-based and centre-based CR at 12-24 months' follow-up. CR, cardiac rehabilitation.

based programmes (fixed-effects RR 1.04, 95\% CI 1.01 to $1.07, \mathrm{I}^{2} 44 \%$; $\mathrm{p}=0.009$ ).

All except four trials (JM Bell. Thesis submitted to the University of London for the degree of Doctor of Philosophy. 1998) ${ }^{35} 3740$ reported adherence to the rehabilitation programme for the duration of the study. Substantial variation in the definition and measures of adherence was seen across studies, so results were not pooled. Seven studies ${ }^{23} \quad 24 \quad 29 \quad 30 \quad 33 \quad 34 \quad 36$ reported no significant difference in adherence between the home-based and centre-based rehabilitation groups, whereas three studies found evidence of higher adherence in patients undertaking home-based $\mathrm{CR}^{25} 32 \quad 38$ (see online supplementary table $\mathrm{C}$ and figure I).

\section{Healthcare costs and usage}

Costs of the intervention in home-based and centrebased settings were reported by four studies and are shown in table 4 . In three of the four studies, healthcare costs associated with CR were lower for the homebased than the centre-based programmes, ${ }^{33} 3438$ but only significantly lower in one study. ${ }^{34}$ Jolly et $a l^{36}$ found home-based CR to be more expensive than centre-based CR. However, when patients' costs were included, no significant difference in overall costs between home-based and centre-based interventions was seen.

No significant differences were observed between the home-based and centre-based groups in terms of healthcare resource use. Eight studies reported measures of healthcare usage including hospital readmissions, primary care consultations and use of secondary care medication (see table 5).

\section{Small study bias}

There was no evidence of funnel plot asymmetry for exercise capacity (Egger test $\mathrm{p}=0.71$ ).

\section{DISCUSSION}

We conducted an updated systematic review and metaanalysis comparing the effects of home-based and supervised centre-based CR. Our study shows no consistent evidence to support differences in patient outcomes for those receiving home-based or centre-based rehabilitation in either the short term ( $\leq 12$ months) or longer term ( $>12$ months). Outcomes considered included exercise capacity, modifiable risk factors (blood pressure, blood lipid concentrations and smoking), HRQoL and cardiac events (mortality, coronary revascularisation and hospital readmissions).

The findings of this updated review are in agreement with those of the previous Cochrane review comparing home-based versus centre-based rehabilitation. ${ }^{21}$ However, importantly, this review now includes data from four trials in 315 patients with heart failure, ${ }^{23-25} 35$ supplementing the evidence base in the previous review that was largely in patients following MI and coronary revascularisation. Our results are consistent with the body of evidence that shows centre-based and homebased delivered disease management to provide similar benefits to cardiac populations. For example, the recent WHICH? trial conducted in Australia indicated that a home-based heart failure management programme was equally effective in terms of outcome (improved HRQoL 
Table 3 Comparison of HRQoL outcomes at follow-up for home-based and centre-based cardiac rehabilitation

\begin{tabular}{|c|c|c|c|c|}
\hline $\begin{array}{l}\text { Trial } \\
\text { Author (year) }\end{array}$ & Follow-up & HRQoL measure & $\begin{array}{l}\text { Outcome values at follow-up or mean } \\
\text { difference }(95 \% \mathrm{Cl}) \\
\text { Mean (SD) } \\
\text { Home vs centre, between group p value }\end{array}$ & $\begin{array}{l}\text { Between-group } \\
\text { difference }\end{array}$ \\
\hline \multirow[t]{7}{*}{ Bell (1998) } & \multirow[t]{7}{*}{10.5 months } & $\begin{array}{l}\text { Nottingham Health } \\
\text { Profile }\end{array}$ & & \\
\hline & & Energy & $18.6(28.4)$ vs $17.3(30.7) \mathrm{p}=0.78^{*}$ & Home $=$ centre \\
\hline & & Pain & $6.6(15.3)$ vs $7.4(15.5) p=0.74^{*}$ & Home $=$ centre \\
\hline & & Emotional reactions & 6.6 (15.3) vs $7.4(15.5) \mathrm{p}=0.74^{*}$ & Home $=$ centre \\
\hline & & Sleep & $6.6(15.3)$ vs 16.9 (22.8) $p=0.0007^{*}$ & Home<centre \\
\hline & & Social isolation & 3.7 (13.6) vs $6.7(15.0) p=0.18^{*}$ & Home $=$ centre \\
\hline & & Physical mobility & 6.9 (13.5) vs 9.1 (15.9) $p=0.33^{*}$ & Home $=$ centre \\
\hline \multirow{4}{*}{$\begin{array}{l}\text { Arthur et al (2002)/ } \\
\text { Smith et al (2004) }\end{array}$} & \multirow{2}{*}{6 months } & SF-36 PCS & $51.2(6.4)$ vs $48.6(7.1) \mathrm{p}=0.003^{*}$ & Home>centre \\
\hline & & MCS & $53.5(6.4)$ vs $52.0(8.1) \mathrm{p}=0.13^{\star}$ & Home $=$ centre \\
\hline & \multirow[t]{2}{*}{18 months } & SF-36 PCS & $48.3(11.7)$ vs $47.6(11.7) p=0.67^{*}$ & Home=Centre \\
\hline & & MCS & $53.0(10.9)$ vs $50.2(10.9) \mathrm{p}=0.07^{*}$ & Home=centre \\
\hline \multirow[t]{5}{*}{ Cowie et al (2012) } & \multirow[t]{5}{*}{3 months } & SF-36 PCS & 34.01 (11.04) vs 31.33 (7.97) $p=0.82$ & Home=centre \\
\hline & & MCS & 44.44 (12.23) vs 48.25 (11.21) $p=0.04$ & Home<centre \\
\hline & & MLWHF total & 37 (NR) vs 32 (NR) $p=0.18$ & Home=centre \\
\hline & & Physical & 21 (NR) vs 19 (NR) $p=0.31$ & Home $=$ centre \\
\hline & & Emotional & $7(\mathrm{NR})$ vs 7 (NR) $p=0.13$ & Home=centre \\
\hline \multirow[t]{3}{*}{$\begin{array}{l}\text { Marchionni et al } \\
\text { (2003) }\end{array}$} & 2 months & $\begin{array}{l}\text { Sickness Impact } \\
\text { Profile }\end{array}$ & $2.83(14.5)$ vs $4.71(11.1) \mathrm{p}=0.09^{*}$ & Home $=$ centre \\
\hline & \multirow{2}{*}{\multicolumn{2}{|c|}{$\begin{array}{l}8 \text { months } \\
14 \text { months }\end{array}$}} & $2.83(14.5)$ vs 3.40 (11.1) $p=0.61^{*}$ & Home $=$ centre \\
\hline & & & 2.00 (8.3) vs $3.70(11.8) p=0.06^{\star}$ & Home $=$ centre \\
\hline \multirow[t]{2}{*}{$\begin{array}{l}\text { Dalal et al (2007)/ } \\
\text { Taylor et al (2007) }\end{array}$} & \multirow[t]{2}{*}{9 months } & $\begin{array}{l}\text { MacNew Global } \\
\text { Score }\end{array}$ & $5.61(1.14)$ vs $5.54(1.10) p=0.71$ & Home $=$ centre \\
\hline & & $E Q-5 D$ & $0.74(0.04)$ vs $0.78(0.04) p=0.57$ & Home $=$ centre \\
\hline \multirow[t]{5}{*}{ Jolly et al (2007) } & \multirow[t]{3}{*}{6 months } & EQ-5D & $0.74(0.26)$ vs $0.76(0.23) p=0.37$ & Home $=$ centre \\
\hline & & SF-12 PCS & $42.28(10.9)$ vs $42.56(10.8) p=0.8$ & Home $=$ centre \\
\hline & & MCS & $49.19(10.1)$ vs $50.33(9.6) p=0.3$ & Home $=$ centre \\
\hline & 12 months & EQ-5D & $0.74(0.27)$ vs $0.76(0.23) \mathrm{p}=0.52^{*}$ & Home $=$ centre \\
\hline & 24 months & EQ-5D & $0.73(0.29)$ vs $0.75(0.26) p=0.39^{*}$ & Home $=$ centre \\
\hline \multirow[t]{9}{*}{ Karapolat et al (2009) } & \multirow[t]{9}{*}{8 weeks } & SF-36 & & \\
\hline & & Physical function & 59.39 (25.35) vs 69.57 (20.94), $p=0.08^{*}$ & Home $=$ centre \\
\hline & & Physical role & $39.81(41.75)$ vs $48.21(45.10) \mathrm{p}=0.43^{*}$ & Home $=$ centre \\
\hline & & Bodily pain & $62.42(30.45)$ vs $74.23(19.66) p=0.07^{*}$ & Home $=$ centre \\
\hline & & General health & $47.25(23.42)$ vs $53.98(25.00) \mathrm{p}=0.33^{*}$ & Home $=$ centre \\
\hline & & Vitality & $66.67(19.82)$ vs $69.81(17.41) \mathrm{p}=0.49^{*}$ & Home $=$ centre \\
\hline & & Social function & $65.33(25.60)$ vs $69.33(25.14) \mathrm{p}=0.52^{*}$ & Home=centre \\
\hline & & Emotional role & $44.74(39.77)$ vs $37.16(39.24) p=0.44^{*}$ & Home $=$ centre \\
\hline & & Mental health & $64.67(19.04)$ vs $70.52(20.37) p=0.22^{*}$ & Home $=$ centre \\
\hline \multirow[t]{4}{*}{ Moholdt et al (2012) } & \multirow[t]{4}{*}{6 months } & MacNew & & \\
\hline & & Emotional domain & $1.2(0.2)$ vs $1.4(0.2) p>0.05$ & Home $=$ centre \\
\hline & & Physical domain & $1.4(0.7)$ vs $1.6(1.1) p>0.05$ & Home $=$ centre \\
\hline & & Social domain & $4.3(0.7)$ vs $4.3(1.0) p>0.05$ & Home $=$ centre \\
\hline \multirow[t]{4}{*}{ Oerkild et al (2011) } & \multirow[t]{2}{*}{3 months } & SF-36 PCS & $1.4(-1.5$ to 4.3$)$ vs, $0.5(-2.4$ to 3.4$), p>0.05$ & Home $=$ centre \\
\hline & & SF-36 MCS & $0.8(-2.6$ to 4.3$)$ vs $-0.2(-3.6$ to 3.4$), p>0.05$ & Home $=$ centre \\
\hline & \multirow[t]{2}{*}{6 months } & SF-36 PCS & $1.0(-1.6$ to 3.6$)$ vs $1.2(-1.4$ to 3.8$), p>0.05$ & Home=centre \\
\hline & & SF-36 MCS & $2.3(-1.1$ to 5.7$)$ vs $2.6(-0.9$ to -6.0$), p>0.05$ & Home $=$ centre \\
\hline Piotrowicz et al (2010) & 8 weeks & SF-36 total & $70.5(25.4)$ vs $69.2(26.4)(p>0.05)$ & Home $=$ centre \\
\hline
\end{tabular}


Table 4 Summary of costs for home-based and centre-based groups

\begin{tabular}{|c|c|c|c|c|c|c|}
\hline $\begin{array}{l}\text { Trial } \\
\text { Author } \\
\text { (year) }\end{array}$ & $\begin{array}{l}\text { Currency } \\
\text { Year of } \\
\text { costs } \\
\text { Follow-up }\end{array}$ & $\begin{array}{l}\text { Cardiac } \\
\text { rehabilitation } \\
\text { programme cost } \\
\text { (per patient) }\end{array}$ & $\begin{array}{l}\text { Programme } \\
\text { costs } \\
\text { considered }\end{array}$ & $\begin{array}{l}\text { Total } \\
\text { healthcare } \\
\text { cost (per } \\
\text { patient) }\end{array}$ & $\begin{array}{l}\text { Additional } \\
\text { healthcare costs } \\
\text { considered }\end{array}$ & Comments \\
\hline $\begin{array}{l}\text { Carlson } \\
\text { et al (2000) }\end{array}$ & $\begin{array}{l}\text { US\$ } \\
\text { Not } \\
\text { reported } \\
6 \text { months }\end{array}$ & $\begin{array}{l}\text { Home: mean } \\
1519 \\
\text { Centre: mean } \\
2349\end{array}$ & $\begin{array}{l}\text { Staff, ECG } \\
\text { monitoring }\end{array}$ & Not reported & & \\
\hline $\begin{array}{l}\text { Marchionni } \\
\text { et al (2003) }\end{array}$ & $\begin{array}{l}\text { US\$ } \\
2000 \\
14 \text { months }\end{array}$ & $\begin{array}{l}\text { Home: mean } \\
1650 \\
\text { Centre: mean } \\
8841\end{array}$ & Not reported & $\begin{array}{l}\text { Home: } \\
21298 \\
\text { Centre: } \\
13246\end{array}$ & Not reported & \\
\hline $\begin{array}{l}\text { Dalal et al } \\
2007\end{array}$ & $\begin{array}{l}\text { UK£ } \\
2002- \\
2003 \\
9 \text { months }\end{array}$ & $\begin{array}{l}\text { Home: mean } 170 \\
\text { (SD 8) } \\
\text { Centre: mean } 200 \\
\text { (SD 3) } \\
\text { Difference: mean } \\
30 \\
95 \% \mathrm{Cl}-45 \text { to } \\
-12 \\
\mathrm{p}<0.0001\end{array}$ & $\begin{array}{l}\text { Staff, exercise } \\
\text { equipment, staff } \\
\text { travel }\end{array}$ & $\begin{array}{l}\text { Home: mean } \\
3279 \text { (SD } \\
374 \text { ) } \\
\text { Centre: mean } \\
3201 \text { (SD } \\
443 \text { ) } \\
\text { Difference: } \\
\text { mean } 78 \\
95 \% \text { CI } \\
-1103 \text { to } \\
1191 \\
p=0.894\end{array}$ & $\begin{array}{l}\text { Rehospitalisations, } \\
\text { revascularisations, } \\
\text { secondary } \\
\text { preventive } \\
\text { medication, } \\
\text { investigations, } \\
\text { primary care } \\
\text { consultations }\end{array}$ & \\
\hline $\begin{array}{l}\text { Jolly et al } \\
2007\end{array}$ & $\begin{array}{l}\text { UK£ } \\
2003 \\
24 \text { months }\end{array}$ & $\begin{array}{l}\text { Home: mean } 198 \\
95 \% \mathrm{Cl} 189 \text { to } \\
209 \\
\text { Centre: mean } 157 \\
95 \% \text { Cl } 139 \text { to } \\
175 \\
p<0.05\end{array}$ & $\begin{array}{l}\text { Staff, telephone } \\
\text { consultations, } \\
\text { staff travel }\end{array}$ & Not reported & & $\begin{array}{l}\text { With inclusion of patient } \\
\text { costs (travel and time), } \\
\text { the societal costs of } \\
\text { home-based and } \\
\text { centre-based cardiac } \\
\text { rehabilitation were not } \\
\text { significantly different. }\end{array}$ \\
\hline
\end{tabular}

and reduced level of hospitalisation) and was associated with lower healthcare costs compared with an equivalent clinic-based programme. ${ }^{45}{ }^{46}$ Given this evidence for disease management programmes, it has been proposed that what matters may be the quality, structure and availability of the follow-up rather than the location of follow-up per se. ${ }^{47}$

Despite level 1A evidence for the recommendation of $\mathrm{CR},{ }^{10-15}$ the uptake of $\mathrm{CR}$ in the UK and internationally remains suboptimal, with participation rates ranging from $20 \%$ to $50 \% .^{7}{ }^{20}{ }^{48-50}$ Recent commentaries have therefore called for alternative ways of providing CR to improve participation. ${ }^{51}$ The choice of a home-based CR intervention provides the opportunity to increase access and uptake. ${ }^{34} 52$

The finding of this review of an absence of evidence of important differences in patient outcomes and healthcare costs between centre-based and home-based CR supports the further provision of home-based CR programmes. Self-management and collaboration with caregivers can also improve uptake and outcomes. ${ }^{53-55}$ The main approach to CR delivery in most countries is a supervised centre-based programme, which usually takes place in a hospital, university or community setting. However, the evidence of this review supports national and international clinical guidelines for the management of heart failure, explicitly recommending home-based CR alongside more traditional supervised centre-based CR programmes. The availability of homebased programmes could increase participation in CR by allowing those unable to attend centre-based CR sessions due to problems involving access and lifestyle commitments to take part in sessions that are individually tailored to suit their needs and fit around their life. This would overcome current capacity constraints within centre-based programmes. Home-based programmes should, as centre-based, be comprehensive in nature (ie, provide education and psychological support in addition to exercise training) and include health professional support such as regular telephone calls and/or home visits, particularly in the early stages of the programme. Providing patients with the choice of centre-based or home-based CR (or a combination of the two) according to their preferences may increase both uptake and adherence. Patients recovering from MI, coronary revascularisation and heart failure should be able to benefit from CR, which can prevent premature cardiovascular death, reduce hospital admissions and improve HRQoL, something that has never been accomplished for the majority of patients. ${ }^{856-59}$ 
Table 5 Summary of healthcare resource use in home-based and centre-based cardiac rehabilitation by months of follow-up

\begin{tabular}{|c|c|c|c|c|c|c|c|c|c|c|}
\hline Trial Author (year) & $\begin{array}{l}\text { Dalal et al } \\
(2007)\end{array}$ & $\begin{array}{l}\text { Gordon et al } \\
\text { (2002) }\end{array}$ & Bell (1998) & & $\begin{array}{l}\text { Carlson et al } \\
(2000)\end{array}$ & $\begin{array}{l}\text { Marchionni } \\
\text { et al (2003) }\end{array}$ & Jolly et al (2007) & & $\begin{array}{l}\text { Moholdt et al } \\
\text { (2012) }\end{array}$ & Oerkild et al (2011) \\
\hline Follow-up & 9 months & 3 months & $0-6$ months & 6-12 months & 6 months & 14 months & 12 months & 24 months & 6 months & 12 months \\
\hline $\begin{array}{l}\text { Rehospitalisations } \\
\mathrm{N} \text { patient }(\%)\end{array}$ & $\begin{array}{l}\text { Home } 9 / 60 \\
(15 \%) \\
\text { Centre } 6 / 44 \\
(14 \%) \\
p=0.845\end{array}$ & & $\begin{array}{l}\text { Home } 21 / 90 \\
(23 \%) \\
\text { Centre 19/88 } \\
(22 \%) \\
p=0.78 \#\end{array}$ & $\begin{array}{l}13 / 89(15 \%) \\
12 / 84(14 \%) \\
p=0.95 \#\end{array}$ & & & & & Not reported & $\begin{array}{l}\text { Number and length of } \\
\text { admissions same } \\
\text { between groups }\end{array}$ \\
\hline Mean (SD) & $\begin{array}{l}\text { Home } 2.2 \\
(0.9) \dagger \\
\text { Centre } 1.2 \\
(0.6) \\
\mathrm{p}=0.383\end{array}$ & & & & & $\begin{array}{l}\text { Home } 0.46 \\
\text { (SE 0.1) } \\
\text { Centre } 0.33 \\
\text { (SE 0.1) } \\
\mathrm{p}=0.49\end{array}$ & $\begin{array}{l}\text { Home } 0.08(0.34) \\
\text { Centre } 0.12(0.41) \\
p=0.3\end{array}$ & $\begin{array}{l}\text { Home } 0.20(0.45) \\
\text { Centre } 0.26(0.57) \\
\mathrm{p}=0.3\end{array}$ & & \\
\hline Mean (SD) & $\begin{array}{l}\text { Home } 6.3 \\
(0.6) \\
\text { Centre } 7.0 \\
(0.9) \\
p=0.514\end{array}$ & & $\begin{array}{l}\text { Home } 6.6 \\
(3.6)^{\star} \\
\text { Centre } 6.6 \\
(4.1) \\
p=1.00 \#\end{array}$ & $\begin{array}{l}5.4(4.1) \\
4.6(3.7) \\
p=0.19 \#\end{array}$ & & & $\begin{array}{l}\text { Home } 0.65(1.14) \\
\text { Centre } 0.72(1.54) \\
p=0.8\end{array}$ & $\begin{array}{l}\text { Home } 0.53(1.14) \\
\text { Centre } 0.66(1.42) \\
p=0.7\end{array}$ & Not reported & Not reported \\
\hline $\begin{array}{l}\text { Secondary } \\
\text { prevention } \\
\text { medication } \\
\mathrm{N} \text { patients (\%) }\end{array}$ & Home $31 / 49$ & Home $36 / 97$ & & & Home 19/38 & & Home $169(72.2 \%)$ & Home $161(71.6 \%)$ & Home: 8/14 (57\%) & Not reported \\
\hline \multirow{2}{*}{$\begin{array}{l}\mathrm{N} \text { patients (\%) } \\
\text { Beta-blockers }\end{array}$} & $\begin{array}{l}(63 \%) \\
\text { Centre 24/34 } \\
(71 \%)\end{array}$ & $\begin{array}{l}(37 \%) \\
\text { Centre } 17 / 45 \\
(38 \%)\end{array}$ & & & Centre 18/42 & & Centre $171(73.4 \%)$ & Centre 164 (72.2\%) & Centre: 15/16 (94\%) & \\
\hline & $p=0.49$ & NS & & & $\mathrm{p}=0.52 \#$ & & $\mathrm{p}=0.8$ & $\mathrm{p}=0.9$ & $\mathrm{p}=0.02^{*}$ & \\
\hline \multirow[t]{3}{*}{ ACE inhibitors } & $\begin{array}{l}\text { Home } 30 / 49 \\
(61 \%)\end{array}$ & $\begin{array}{l}\text { Home 25/97 } \\
(26 \%)\end{array}$ & & & Home $4 / 38$ & & Home $176(75.2 \%)^{*}$ & Home $177(78.7 \%)^{*}$ & Home: $1 / 14(7 \%)$ & \\
\hline & $\begin{array}{l}\text { Centre 24/33 } \\
(73 \%)\end{array}$ & $\begin{array}{l}\text { Centre 8/45 } \\
(18 \%)\end{array}$ & & & Centre $4 / 42$ & & Centre $161(69.1 \%)^{*}$ & Centre $156(68.7 \%)^{\star}$ & Centre: $0 / 16(0 \%)$ & \\
\hline & $\mathrm{p}=0.28$ & NS & & & $\mathrm{p}=0.88 \#$ & & $\mathrm{p}=0.1$ & $\mathrm{p}=0.02$ & $\mathrm{p}=0.28^{*}$ & \\
\hline \multirow[t]{3}{*}{ Statins } & $\begin{array}{l}\text { Home } 48 / 49 \\
(98 \%)^{*}\end{array}$ & $\begin{array}{l}\text { Home 73/97 } \\
(75 \%)\end{array}$ & & & Home $5 / 38$ & & Home $216(92.3 \%)^{\star *}$ & Home $195(86.7 \%)^{\star \star}$ & Home: $6 / 14(43 \%)$ & \\
\hline & $\begin{array}{l}\text { Centre 30/35 } \\
(88 \%)^{*}\end{array}$ & $\begin{array}{l}\text { Centre } 33 / 45 \\
(73 \%)\end{array}$ & & & Centre $8 / 42$ & & Centre $221(94.8 \%)^{\star \star}$ & Centre $206(90.7 \%)^{\star *}$ & Centre: $2 / 16(13 \%)$ & \\
\hline & $\mathrm{p}=0.18$ & NS & & & $\mathrm{p}=0.47 \#$ & & $\mathrm{p}=0.3$ & $\mathrm{p}=0.2$ & $\mathrm{p}=0.07^{*}$ & \\
\hline \multirow[t]{3}{*}{ Antiplatelets } & $\begin{array}{l}\text { Home } 46 / 49 \\
(94 \%)\end{array}$ & $\begin{array}{l}\text { Home } 94 / 97 \\
(97 \%)^{*}\end{array}$ & & & Home 15/38 & & Home $227(97.0 \%) \dagger$ & Home $214(95.1 \%) \dagger$ & $\begin{array}{l}\text { Home: } 14 / 14 \\
(100 \%)\end{array}$ & \\
\hline & $\begin{array}{l}\text { Centre 30/35 } \\
(86 \%)\end{array}$ & $\begin{array}{l}\text { Centre } 45 / 45 \\
(100 \%)^{\star}\end{array}$ & & & Centre 20/42 & & Centre $226(97.0 \%) \dagger$ & Centre $220(96.9 \%) \dagger$ & $\begin{array}{l}\text { Centre: } 14 / 16 \\
(100 \%)\end{array}$ & \\
\hline & $p=0.21$ & NS & & & $\mathrm{p}=0.54 \#$ & & $p=1.0$ & $\mathrm{p}=0.3$ & $\mathrm{p}=0.18^{\star}$ & \\
\hline Comments & $\begin{array}{l}\text { tnumber of } \\
\text { nights } \\
\text { *lipid } \\
\text { lowering } \\
\text { drugs }\end{array}$ & $\begin{array}{l}\text { *antiplatelets \& } \\
\text { anticoagulants } \\
\text { NS: not } \\
\text { statistically } \\
\text { significant }\end{array}$ & $\begin{array}{l}{ }^{*} \mathrm{GP} \\
\text { consultations }\end{array}$ & & $\begin{array}{l}\text { \#P-value calculated } \\
\text { by authors of the } \\
\text { present report }\end{array}$ & $\begin{array}{l}\text { SE: standard } \\
\text { error }\end{array}$ & $\begin{array}{l}\text { *angiotensin-converting- } \\
\text { enzyme inhibitor or } \\
\text { Angiotensin II receptor } \\
\text { antagonist } \\
{ }^{* *} \text { cholesterol-lowering drugs } \\
\text { †Aspirin or antiplatelet } \\
\text { drugs }\end{array}$ & $\begin{array}{l}\text { *angiotensin-converting- } \\
\text { enzyme inhibitor or } \\
\text { Angiotensin II receptor } \\
\text { antagonist } \\
{ }^{* *} \text { cholesterol-lowering drugs } \\
\text { †Aspirin or antiplatelet } \\
\text { drugs }\end{array}$ & $\begin{array}{l}{ }^{*} p \text { Value calculated } \\
\text { by authors of the } \\
\text { present report. }\end{array}$ & \\
\hline
\end{tabular}

Figures are means (SD or $95 \% \mathrm{Cl})$.

$\mathrm{GP}$, general practitioner; NS, not statistically significant; SD, standard deviation. 


\section{Limitations}

The generally poor level of reporting in the included studies made it difficult to assess their methodological quality and thereby judge their risk of bias. However, we did find some improvements in the quality of reporting in recently published studies. Details of interventions were often poorly reported, so it was also unclear whether the CR programmes delivered in the included studies meet the service quality recommendations such as those of the UK CR standards. ${ }^{7}$ Our review is limited by statistical heterogeneity in a number of outcomes across trials, which may reflect the variety of centrebased interventions. In addition, most studies were of relatively short duration; only three trials reported outcomes beyond 12 months of follow-up. ${ }^{32} 3638$ Given the variation in outcome measures across trials, we used the SMD. This method assumes that differences in SDs among studies reflect differences in measurement scales and not real differences in variability of study populations. ${ }^{28}$ However, this assumption may be problematic in the context of this systematic review where the study populations vary in their indication.

Nevertheless, we believe this to be the most comprehensive review of evidence until now, summarising the results of randomised trials in over 2000 patients.

\section{CONCLUSIONS}

Home-based and hospital-based or centre-based CR have similar benefits in terms of clinical events, risk factors and HRQoL outcomes in patients after MI or coronary revascularisation and in those with heart failure. Together with the absence of evidence of differences in healthcare costs, and given the current suboptimal uptake of CR services, these findings strongly support the further roll-out of home-based CR programmes, thus offering patients improved access and choice.

Future research should focus on the long-term effects of home-based versus centre-based CR, and wellreported adequately powered head-to-head randomised studies are needed in patient groups poorly represented in this review, including angina pectoris.

\author{
Author affiliations \\ ${ }^{1}$ Department of Research, Development \& Innovation, Royal Cornwall, \\ Hospitals NHS Trust, Truro, UK \\ ${ }^{2}$ Institute of Health Research (Primary Care), University of Exeter Medical \\ School, Exeter, Devon, UK \\ ${ }^{3}$ Institute for Applied Health Research, University of Birmingham, \\ Birmingham, UK \\ ${ }^{4}$ Agency for Health Technology Assessment and Tariff System, Warsaw, \\ Poland \\ ${ }^{5}$ Cardiac Rehabilitation, University Hospital Ayr, Ayr, UK \\ ${ }^{6}$ Institute of Bioengineering, School of Engineering and Materials Science, \\ Queen Mary University of London, London, UK
}

Acknowledgements The authors would like to thank Nicole Martin of the Cochrane Heart Group editorial team for updating the search strategies and running the updated searches.

Contributors All named authors have contributed to the manuscript in compliance with the Uniform Requirements for Manuscripts Submitted to
Biomedical Journals. RST and RJN led the design of this review update. Study selection was undertaken by RST and RJN. RST, RJN and SGD undertook the data extraction and risk of bias assessment. RST and RJN undertook the data analysis. SAB undertook the first draft of the paper and all authors commented on draft versions of the paper. All authors have read and approved the final version of the manuscript.

Funding $\mathrm{SAB}, \mathrm{HMD}$ and RST are supported by the National Institute for Health Research (NIHR) under its Programme Grants for Applied Research Programme (Grant Reference Number RP-PG-1210-12004). RST and SGD are supported by the NIHR Collaboration for Leadership in Applied Health Research and Care South West Peninsula (PenCLAHRC) at the Royal Devon and Exeter National Health Service (NHS) Foundation Trust. KJ is part-funded by the NIHR Collaboration for Leadership in Applied Health Research West Midlands.

Disclaimer The views expressed are those of the author(s) and not necessarily those of the NHS, the NIHR or the Department of Health.

Competing interests RST is an author on a number of other Cochrane reviews of cardiac rehabilitation (CR). HMD, RST and KJ are investigators on the REACH-HF programme of research, which is developing and evaluating a home-based CR intervention for people with heart failure and their carers (NIHR PGfAR RP-PG-0611-12004).

Provenance and peer review Not commissioned; externally peer reviewed.

Data sharing statement The study protocol and study data are available from the corresponding author on request.

Open Access This is an Open Access article distributed in accordance with the Creative Commons Attribution Non Commercial (CC BY-NC 4.0) license, which permits others to distribute, remix, adapt, build upon this work noncommercially, and license their derivative works on different terms, provided the original work is properly cited and the use is non-commercial. See: http:// creativecommons.org/licenses/by-nc/4.0/

\section{REFERENCES}

1. World Health Organization (WHO) 2015. WHO Mortality Database: 25 November 2015. http://www.who.int/healthinfo/statistics/mortality rawdata/en/index.html (accessed 25 May 2016).

2. British Heart Foundation (BHF). Heart statistics. 2015. http://www. bhf.org.uk/research/heart-statistics (accessed 22 Dec 2015).

3. Balady GJ, Williams MA, Ades PA, et al, American Heart Association Exercise, Cardiac Rehabilitation, and Prevention Committee; Council on Clinical Cardiology; Councils on Cardiovascular Nursing, Epidemiology and Prevention, and Nutrition, Physical Activity, and Metabolism; American Association of Cardiovascular and Pulmonary Rehabilitation. Core components of cardiac rehabilitation/secondary prevention programs: 2007 update: a scientific statement from the American Heart Association Exercise, Cardiac Rehabilitation, and Prevention Committee, the Council on Clinical Cardiology; the councils on Cardiovascular Nursing, Epidemiology and Prevention, and Nutrition, Physical Activity, and Metabolism; and the American Association of Cardiovascular and Pulmonary Rehabilitation. J Cardiopulm Rehabil Prev 2007;27:121-9.

4. Piepoli M, Maugeri FS, Campana M, et al. Experience from controlled trials of physical training in chronic heart failure. Protocol and patient factors in effectiveness in the improvement of exercise tolerance. Eur Heart J 1998;19:466-75.

5. Piepoli MF, Corrà U, Benzer W, et al, Cardiac Rehabilitation Section of the European Association of Cardiovascular Prevention and Rehabilitation. Secondary prevention through cardiac rehabilitation: from knowledge to implementation. A position paper from the Cardiac Rehabilitation Section of the European Association of Cardiovascular Prevention and Rehabilitation. Eur J Cardiovasc Prev Rehabil 2010;17:1-17.

6. Corrà U, Giannuzzia P, Adamopoulos S, et al, Working Group on Cardiac Rehabilitation and Exercise Physiology of the European Society of Cardiology. Executive summary of the position paper of the Working Group on Cardiac Rehabilitation and Exercise Physiology of the European Society of Cardiology (ESC): core components of cardiac rehabilitation in chronic heart failure. Eur J Cardiovasc Prev Rehabil 2005;12:321-5.

7. British Association for Cardiovascular Prevention and Rehabilitation (BACPR). The BACPR standards and core components for cardiovascular disease prevention and rehabilitation. 2nd edn. 2012. 
http://www.bacpr.com/resources/46c_bacpr_standards_and_core_ components 2012.pdf (accessed 14 Oct 2015).

8. Anderson L, Oldridge N, Thompson DR, et al. Exercise-based cardiac rehabilitation for coronary heart disease: Cochrane systematic review and meta-analysis. J Am Coll Cardiol 2016;67:1-12.

9. Taylor RS, Sagar VA, Davies EJ, et al. Exercise-based rehabilitation for heart failure. Cochrane Database Syst Rev 2014;(4):CD003331.

10. National Institute for Health and Care Excellence (NICE). Chronic heart failure. Management of chronic heart failure in adults in primary and secondary care. NICE Clinical Guideline CG108, 2010.

11. National Institute for Health and Care Excellence (NICE). MI secondary prevention. Secondary Prevention in Primary and Secondary Care for Patients Following a Myocardial Infarction. NICE Clinical Guideline CG172, 2013.

12. McMurray JV, Adamopoulos S, Anker SD, et al, ESC Committee for Practice Guidelines. ESC Guidelines for the diagnosis and treatment of acute and chronic heart failure 2012 The Task Force for the Diagnosis and Treatment of Acute and Chronic Heart Failure 2012 of the European Society of Cardiology. Developed in collaboration with the Heart Failure Association (HFA) of the ESC. Eur Heart $J$ 2012;33:1787-847.

13. Yancy CW, Jessup M, Bozkurt B, et al, American College of Cardiology Foundation; American Heart Association Task Force on Practice Guidelines. 2013 ACCF/AHA Guideline for the management of heart failure. A report of the American College of Cardiology Foundation/American Heart Association Task Force on Practice Guidelines. J Am Coll Cardiol 2013;62:e147-239.

14. Piepoli MF, Corrà U, Adamopoulos $\mathrm{S}$, et al. Secondary prevention in the clinical management of patients with cardiovascular diseases. Core components, standards and outcome measures for referral and delivery: a policy statement from the cardiac rehabilitation section of the European Association for Cardiovascular Prevention \& Rehabilitation. Endorsed by the Committee for Practice Guidelines of the European Society of Cardiology. Eur J Prev Cardiol 2014;21:664-81.

15. Balady GJ, Ades PA, Bittner VA, et al. American Heart Association Science Advisory and Coordinating Committee. Referral, enrolment, and delivery of cardiac rehabilitation/secondary prevention programs at clinical centers and beyond: a presidential advisory from the American Heart Association. Circulation 2011;124:2951-60.

16. Dalal HM, Wingham J, Palmer J, et al, REACH-HF investigators. Why do so few patients with heart failure participate in cardiac rehabilitation? A cross-sectional survey from England, Wales and Northern Ireland. BMJ Open 2012;2:e000787.

17. Karmali KN, Davies P, Taylor F, et al. Promoting patient uptake and adherence in cardiac rehabilitation. Cochrane Database Syst Rev 2014;(6):CD007131.

18. Beswick AD, Rees K, Griebsch I, et al. Provision, uptake and cost of cardiac rehabilitation programmes: improving services to underrepresented groups. Health Technol Assess 2004;8:iii-iv, ix-x, 1-152.

19. Heart Manual Department 2015. Heart manual programmes. Edinburgh: Heart Manual Department, NHS Lothian, 2015. http:// www.theheartmanual.com/Programmes (accessed 26 Jan 2016).

20. National Audit of Cardiac Rehabilitation (NACR) 2015. The National Audit of Cardiac Rehabilitation Annual Statistical Report 2015. British Heart Foundation. http://www.cardiacrehabilitation.org.uk/ docs/NACR\%20Annual\%20Statistical\%20Report\%202015.pdf (accessed 4 Jan 2016)

21. Taylor RS, Dalal H, Jolly K, et al. Home-based versus centre-based cardiac rehabilitation. Cochrane Database Syst Rev 2010;(1): CD007130.

22. Dalal HM, Zawada A, Jolly K, et al. Home based versus centre based cardiac rehabilitation: Cochrane systematic review and metaanalysis. BMJ 2010;340:b5631.

23. Cowie A, Thow MK, Granat MH, et al. Effects of home versus hospital-based exercise training in chronic heart failure. Int $J$ Cardiol 2012;158:296-8.

24. Karapolat H, Demir E, Bozkaya YT, et al. Comparison of hospitalbased versus home-based exercise training in patients with heart failure: effects on functional capacity, quality of life, psychological symptoms, and hemodynamic parameters. Clin Res Cardiol 2009;98:635-42.

25. Piotrowicz E, Baranowski R, Bilinska M, et al. A new model of homebased telemonitored cardiac rehabilitation in patients with heart failure: effectiveness, quality of life, and adherence. Eur $J$ Heart Fail 2010;12:164-71.

26. Moher D, Liberati A, Tetzlaff J, et al. PRISMA Group. Preferred Reporting Items for Systematic Reviews and Meta-Analyses: the PRISMA statement. PLoS Med 2009;6:e1000097.

27. Jolly K, Taylor RS, Lip GY. Home-based cardiac rehabilitation compared with centre-based rehabilitation and usual care: a systematic review and meta-analysis. Int J Cardiol 2006;111: 343-51.

28. Higgins JPT, Green S. eds. Cochrane handbook for systematic reviews of interventions 5.1.0. (updated March 2011). The Cochrane Collaboration, 2011. http://www.cochrane.org/training/cochranehandbook. (accessed 23 Dec 2015).

29. Miller $\mathrm{NH}$, Haskell WL, Berra $\mathrm{K}$, et al. Home versus group exercise training for increasing functional capacity after myocardial infarction. Circulation 1984;70:645-9.

30. Gordon NF, English CD, Contractor AS, et al. Effectiveness of three models for comprehensive cardiovascular disease risk reduction. Am J Cardiol 2002;89:1263-8.

31. Egger M, Davey Smith G, Schneiger M, et al. Bias in meta-analysis detected by a simple, graphical test. BMJ 1997;315:629-34.

32. Arthur HM, Smith KM, Kodis J, et al. A controlled trial of hospital versus home-based exercise in cardiac patients. Med Sci Sports Exerc 2002;34:1544-50.

33. Carlson JJ, Johnson JA, Franklin BA, et al. Program participation, exercise adherence, cardiovascular outcomes, and program cost of traditional versus modified cardiac rehabilitation. Am J Cardiol 2000;86:17-23.

34. Dalal HM, Evans PH, Campbell JL, et al. Home-based versus hospital-based cardiac rehabilitation after myocardial infarction: a randomized trial with preference arms - Cornwall Heart Attack Rehabilitation Management Study (CHARMS). Int J Cardiol 2007;119:202-11.

35. Daskapan A, Arikan H, Caglar N, et al. Comparison of supervised exercise training and home-based exercise training in chronic heart failure. Saudi Med J 2005;26:842-7.

36. Jolly K, Taylor R, Lip GY, et al. The Birmingham Rehabilitation Uptake Maximisation Study (BRUM). Home-based compared with hospital-based cardiac rehabilitation in a multi-ethnic population: cost-effectiveness and patient adherence. Health Technol Assess 2007:11:1-118.

37. Kassaian M, Maleki M, Noohi F, et al. Comparing effects of supervised vs. home-based cardiac rehabilitation. Iran Heart $J$ 2000;1:95-102.

38. Marchionni N, Fattirolli F, Fumagalli S, et al. Improved exercise tolerance and quality of life with cardiac rehabilitation of older patients after myocardial infarction: results of a randomized, controlled trial. Circulation 2003;107:2201-6.

39. Sparks KE, Shaw DK, Eddy D, et al. Alternatives for cardiac rehabilitation patients unable to return to a hospital-based program Heart Lung 1993;22:298-303.

40. Wu SK, Lin YW, Chen CL, et al. Cardiac rehabilitation vs. home exercise after coronary artery bypass graft surgery: a comparison of heart rate recovery. Am J Phys Med Rehabil 2006;85: 711-17.

41. Moholdt T, Bekken Vold M, Grimsmo J, et al. Home-based aerobic interval training improves peak oxygen uptake equal to residential cardiac rehabilitation: a randomized, controlled trial. PLOS ONE 2012;7:e41199.

42. Oerkild B, Frederiksen M, Hansen JF, et al. Home-based cardiac rehabilitation is as effective as centre-based cardiac rehabilitation among elderly with coronary heart disease: results from a randomised clinical trial. Age Ageing 2011:40:78-85.

43. Smith KM, McKelvie RS, Thorpe KE, et al. Six-year follow-up of a randomised controlled trial examining hospital versus home-based exercise training after coronary artery bypass graft surgery. Heart 2011;97:1169-74

44. American Association of Cardiovascular and Pulmonary Rehabilitation (AACVPR). Guidelines for Cardiac Rehabilitation and Secondary Prevention Programs 5th edition, Champaign, IL: Human Kinetics, 2005. In: Association of Chartered Physiotherapists in Cardiac Rehabilitation (ACPICR) 2015. Standards for physical activity and exercise in the cardiovascular population: 2015, 3rd edition (appendix E, p45-46). http://acpicr $\mathrm{com} / \mathrm{sites} /$ default/files/ACPICR\%20Standards\%202015.pdf (accessed 26 May 2016).

45. Stewart S, Carrington MJ, Horowitz JD, et al. Prolonged impact of home versus clinic-based management of chronic heart failure: extended follow-up of a pragmatic, multicentre randomized trial cohort. Int J Cardiol 2014;174:600-10.

46. Maru S, Byrnes J, Carrington MJ, et al. Cost-effectiveness of home versus clinic-based management of chronic heart failure: extended follow-up of a pragmatic, multicentre randomized trial cohort-The WHICH? study (Which Heart Failure Intervention Is Most CostEffective \& Consumer Friendly in Reducing Hospital Care). Int $J$ Cardiol 2015;201:368-75.

47. Jaarsma T, Strömberg A. Heart failure clinics are still useful (more than ever?). Can J Cardiol 2014;30:272-5. 
48. Menezes AR, Lavie CJ, Milani RV, et al. Cardiac rehabilitation in the United States. Prog Cardiovasc Dis 2014;56:522-9.

49. Jelinek MV, Thompson DR, Ski C, et al. 40 years of cardiac rehabilitation and secondary prevention in post-cardiac ischaemic patients. Are we still in the wilderness? Int J Cardiol 2015;179: 153-9.

50. Forman DE, Sanderson BK, Josephson RA, et al, American College of Cardiology's Prevention of Cardiovascular Disease Section. Heart failure as a newly approved diagnosis for cardiac rehabilitation: challenges and opportunities. J Am Coll Cardiol 2015;65: 2652-9.

51. Lavie CJ, Arena R, Franklin BA. Cardiac rehabilitation and healthy life-style interventions: rectifying program deficiencies to improve patient outcomes. J Am Coll Cardiol 2016;67:13-15.

52. Wingham J, Dalal HM, Sweeney KG, et al. Listening to patients: choice in cardiac rehabilitation. Eur J Cardiovasc Nurs 2006;5: 289-94.

53. Ades PA, Keteyian SJ, Balady GJ, et al. Cardiac rehabilitation exercise and self-care for chronic heart failure. JACC Heart Fail 2013;1:540-7.

54. Buck HG, Harkness K, Wion R, et al. Caregivers' contributions to heart failure self-care: a systematic review. Eur $\mathrm{J}$ Cardiovasc Nurs 2015; 14:79-89.
55. Clark AM, Spaling M, Harkness $K$, et al. Determinants of effective heart failure self-care: a systematic review of patients' and caregivers' perceptions. Heart 2014;100:716-21.

56. Healthcare Commission. Coronary heart disease: survey of patients. Healthcare Commission, 2004. http://www.nhssurveys.org/Filestore/ CQC/CHD_KF_2004.pdf

57. Grace SL, Gravely-Witte S, Brual J, et al. Contribution of patient and physician factors to cardiac rehabilitation enrolment: a prospective multilevel study. Eur J Cardiovasc Prev Rehabil 2008;15:548-56

58. Grace SL, McDonald J, Fishman D, et al. Patient preferences for home-based versus hospital-based cardiac rehabilitation. J Cardiopulm Rehabil 2005;25:24-9.

59. Ades PA, Waldmann ML, McCann WJ, et al. Predictors of cardiac rehabilitation participation in older coronary patients. Arch Intern Med 1992;152:1033-5.

60. Smith KM, Arthur HM, McKelvie RS, et al. Differences in sustainability of exercise and health-related quality of life outcomes following home- or hospital-based cardiac rehabilitation. Eur $J$ Cardiovasc Prev Rehabil 2004;11:313-9.

61. Taylor RS, Watt A, Dalal HM, et al. Home-based cardiac rehabilitation versus hospital-based rehabilitation: a cost effectiveness analysis. Int J Cardiol 2007;119:196-201. 